\section{ALIRAN INOVASI KERAJINAN RAMBUT PALSU DALAM PENGEMBANGAN INDUSTRI KREATIF DI PURBALINGGA}

\author{
Devi Rahma Jayanti*, A Artiningsih \\ Departemen Perencanaan Wilayah dan Kota, \\ Fakultas Teknik, Universitas Diponegoro, Semarang
}

Jurnal Pengembangan Kota (2020)

Volume 8 No. 1 (22-32)

Tersedia online di:

http://ejournal2.undip.ac.id/index.php/jpk DOI: $10.14710 / j p k .8 .1 .22-32$

\begin{abstract}
Abstrak. Kemampuan beradaptasi dengan cara merespon permintaan pasar dan inovasi pengolahan kerajinan rambut palsu di Purbalingga menjadikannya mampu bertahan hingga 68 tahun. Sebagai modal keberlanjutan usaha, inovasi mencakup proses pelaku usaha mengakses ide kreatif dari berbagai sumber dan menerapkannya sesuai kondisi dan kebutuhan. Inovasi mampu memberikan nilai tambah melalui berbagai penciptaan alternatif produk rambut palsu. Secara empiris inovasi tidak hanya berasal dari keahlian yang diwariskan, namun juga dari kepekaan memanfaatkan ide dan pengetahuan baru dari sumber lain. Aliran inovasi memberikan ilustrasi asal sumber ide kreatif dan bagaimana ide tersebut sampai kepada pelaku usaha, sehingga mampu menghasilkan diversifikasi produk, perluasan jejaring pemasaran maupun perolehan bahan baku untuk efisiensi proses produksi. Tujuan penelitian ini berpa identifikasi aliran inovasi industri kreatif kerajinan rambut palsu. Penelitian ini menggunakan metode kualitatif melalui pendekatan studi kasus. Wawancara mendalam dilakukan kepada 10 narasumber yang dipilih menggunakan teknik snowballing. Analisis kronologis perkembangan usaha diilustrasikan secara deskriptif dan spasial didukung teknik triangulasi menggunakan desk study. Temuan penelitian menunjukkan aliran inovasi kerajinan rambut palsu di Purbalingga tidak hanya bersumber dari pengetahuan yang diwariskan, tetapi juga pengetahuan baru dari interaksi dengan pabrik rambut palsu, pelatihan dan mitra kerja pemasaran. Perluasan perkembangan pasar hingga skala regional juga berperan terhadap aliran inovasi dan munculnya kerajinan rambut palsu di luar Purbalingga. Aliran inovasi juga terjadi antar pelaku usaha melalui interaksi dan pembelajaran sosial dalam hubungan keluarga, tenaga kerja, dan kompetisi usaha.
\end{abstract}

Kata kunci: Industri Kreatif; Inovasi; Kerjasama; Transfer Pengetahuan

[Title: Innovation Flow on Home-made Wigs as a Creative Industry Development in Purbalingga]. Adaptive capacity on which an entrepreneur responds to their market demand became an important innovation attempt on how homemade wigs SMEs survive for 68 years. Instead of skill passed down through generations, there were several other sources as input for the birth of business innovation. The process of obtaining new ideas and knowledge from other sources will create a flow of innovation that encourages business development. The flow of innovation illustrated the source of ideas and how ideas reach business ventures. Eventually, they produce innovation for product development, marketing, and new raw materials for the production process improvement. The purpose of this study is to identify the innovation flow originating from the initiation up to the development process owned by the business. It is a case study research that occupying in-depth interview with 10 business owner/employee which selected by purposive sampling and snowball technique. Time-line business development illustrates innovation flow in descriptive narrative and spatial cognition. It supported by triangulation techniques using desk study. The results showed that the innovation flow generated from the business not only comes from the inheritance of skills from generations but also from the wig factory, training activity, and business partners in the marketing network. The expansion of market development on a regional scale also give a significant effect on innovation and new home-made wigs SMEs outside Purbalingga. The flow of innovation also occurs within businesses by social interaction and learning through family, employee, and competitive relations.

Keyword: Creative Industries; Innovation; Cooperation; Knowledge Transfer

Cara Mengutip: Jayanti, D. R., \& Artiningsih, A. (2020). Aliran Inovasi Kerajinan Rambut Palsu Dalam Pengembangan Industri Kreatif di Purbalingga. Jurnal Pengembangan Kota. Vol 8 (1): 23-32. DOI: 10.14710/jpk.8.1.23-32 


\section{PENDAHULUAN}

Kondisi perekonomian di negara berkembang tidak terkecuali Indonesia dihadapkan pada kerentanan berupa kemiskinan (Cobbinah, Erdiaw-Kwasie, \& Amoateng, 2015). Kemiskinan menjadi salah satu isu perkembangan perkotaan yang sangat diperhatikan dunia. Hal ini terkait dengan upaya mewujudkan SDG's dimana pada tahun 2030 ditargetkan tidak ada kemiskinan diseluruh dunia. Kabupaten Purbalingga termasuk daerah miskin di Jawa Tengah dengan angka kemiskinan mencapai 18\% (Antoni, 2019). Keterbatasan terhadap akses pekerjaan dan rendahnya sumber daya manusia menjadi penyebab tingginya angka kemiskinan di Purbalingga. Kemiskinan menjadi salah satu penyebab kesejahteraan masyarakat rendah (Cobbinah, Black, \& Thwaites, 2013). Situasi ini memberi ruang terhadap industri kreatif yang mampu berkontribusi terhadap peningkatan penyerapan tenaga kerja.

Industri kreatif merupakan pengembangan industri yang bergantung pada SDM berupa ide-ide kreatif. Pengembangan industri yang tidak lagi bergantung pada sumber daya tidak terbarukan tentunya akan lebih berkelanjutan. Industri kreatif menuntut untuk melakukan eksploitasi kekayaan intelektual yang melahirkan ide kreatif dan inovasi (Boccella \& Salerno, 2016). Kemampuan industri kreatif dalam menghadapi kemiskinan perkotaan mendorong perlunya mendukung perkembangan industri kreatif jangka panjang, salah satunya dengan menjamin ketersediaan aset utama industri kreatif yaitu ide kreatif dan inovasi dari pelaku usaha. Inovasi merupakan faktor utama yang mendukung perkembangan produk, pemasaran, dan penggunaan bahan baku. Proses kreatif menjadi modal bagi pelaku usaha dalam mengembangkan produk secara dinamis. Inovasi menjadi hal utama dalam proses mengembangkan sebuah industri kreatif (Moore, 2014).

Industri kreatif rambut palsu di Karangbanjar merupakan industri yang berkembang dari warisan turun temurun (Arifin \& Sugiyanto, 2015). Keahlian yang diwariskan menjadi modal penting dalam perkembangan industri kreatif rambut palsu. Hal ini sesuai degan pendapat Fahmi, McCann, dan Koster (2017) bahwa panerapan industri kreatif di negara berkembang seperti Indonesia cenderung mengembangkan produk kerajinan yang merupakan warisan turun temurun. Industri kreatif rambut palsu sudah berkembang di Karangbanjar sejak tahun 1951. Keahlian mengolah rambut menjadi warisan turun temurun dan juga menjadi cikal bakal bagi berkembangnya kerajinan rambut palsu di Indonesia (Ramadhana, 2016). Pengembangan warisan turun temurun berupa keahlian melalui pengembangan industri kreatif mampu memberikan nilai tambah bagi produk yang dihasilkan (Veselá \& Klimová, 2014). Keahlian yang diwariskan menjadi salah satu sumber dalam aliran inovasi. Akan tetapi aliran inovasi yang mendukung perkembangan industri kreatif rambut palsu juga didorong oleh adanya inovasi dari pelaku usaha. Proses belajar pelaku usaha untuk memperoleh ide dan mengembangkan inovasi hingga mampu mengembangkan industri kreatif rambut palsu merupakan bentuk upaya pelaku usaha beradaptasi pada perubahan lingkungan yang dinamis dalam hal ini adalah tren produk (Sukarno, 2009).

Aliran inovasi akan menggambarkan perjalanan asal ide kreatif dari berbagai sumber hingga sampai ke pelaku usaha. Perjalanan panjang perkembangan industri kreatif rambut palsu tentunya tidak lepas dengan adanya transfer pengetahuan dan aliran inovasi. Aliran inovasi bisa terjadi akibat perluasan pasar (Moore, 2014), adaptasi dari perubahan lingkungan yang dinamis (Sukarno, 2009), unsur kepercayaan dalam hubungan keluarga (Chuluunbaatar, Luh, \& Kung, 2014), kerjasama dalam kemitraan (Liu, 2018) dan ide kreatif sebagai pengetahuan baru (Hidayat \& Asmara, 2017).

Keterampilan pelaku usaha dalam mengolah rambut palsu sudah ada sejak 68 tahun yang lalu. Perubahan lingkungan yang sangat dinamis juga mengakibatkan pelaku usaha harus belajar dan mengikuti perkembangan zaman. Inovasi menjadi

\footnotetext{
ISSN 2337-7062 @ 2020

This is an open access article under the CC-BY-NC-ND license (http://creativecommons.org/licenses/by-nc-sa/4.0/). - lihat halaman depan @ 2020

*Email devirahma173@gmail.com
}

Diterima 18 Februari 2020, disetujui 25 Juni 2020 
bentuk dari upaya adaptasi pelaku usaha dalam menghadapi kerentanan dan tantangan dalam mengembangkan usaha industri kreatif rambut palsu. Inovasi yang dimiliki pelaku usaha merupakan hasil belajar dari berbagai sumber. Proses pelaku usaha memperoleh inovasi dari berbagai sumber menjadi sebuah aliran inovasi. Hal baru yang dikaji dalam penelitian ini adalah bahwa rasa empati terhadap kesulitan orang lain mampu menjadi fondasi bagi cikal bakal tumbuhnya peluang usaha bahkan di area pedalaman dan menjadi inspirasi atas munculnya kompetisi usaha sebagai aliran inovasi yang penting dalam membangun pasar ekspor.

Aliran inovasi mempengaruhi kemampuan pelaku usaha dalam mengembangkan industri kreatif hingga dapat berkembang dalam tiga generasi memberikan pengaruh terhadap kesejahteraan masyarakat. Aliran inovasi pada industri kreatif rambut palsu sudah mampu mengembangkan Karangbanjar menjadi sentra rambut palsu. Industri ini berkontribusi menyerap 30\% tenaga kerja dan berhasil meningkatkan pendapatan hingga $80 \%$. Industri kreatif rambut palsu secara umum di Purbalingga, sudah mampu menjadi keunggulan komparatif bagi daerah (Arifin \& Sugiyanto, 2015).

Penelitian ini bertujuan untuk mengidentifikasi aliran inovasi pelaku usaha industri kreatif rambut palsu hingga mampu mengikuti perkembangan tren dan bertahan selama tiga generasi. Bagaimana pelaku usaha memperoleh ide untuk berinovasi dan mengalirkan ide kepada pelaku usaha lain menarik untuk diteliti. Mengapa kota kecil di pedalaman Jawa Tengah mampu berkompetisi dalam pasar ekspor?

\section{METODE PENELITIAN}

Penelitian ini dilakukan pada industri kreatif rambut palsu di Desa Karangbanjar. Desa tersebut merupakan salah satu desa di Kecamatan Bojongsari, Kabupaten Purbalingga. Luas desa ini adalah 148 hektar dan terdiri dari 5 Dusun. Industri kreatif di desa ini hanya berkembang pesat di tiga dusun yaitu Dusun Pakuncen, Karangbanjar dan Karangsempu, sedangkan dua dusun lain hanya terdapat beberapa pelaku usaha.

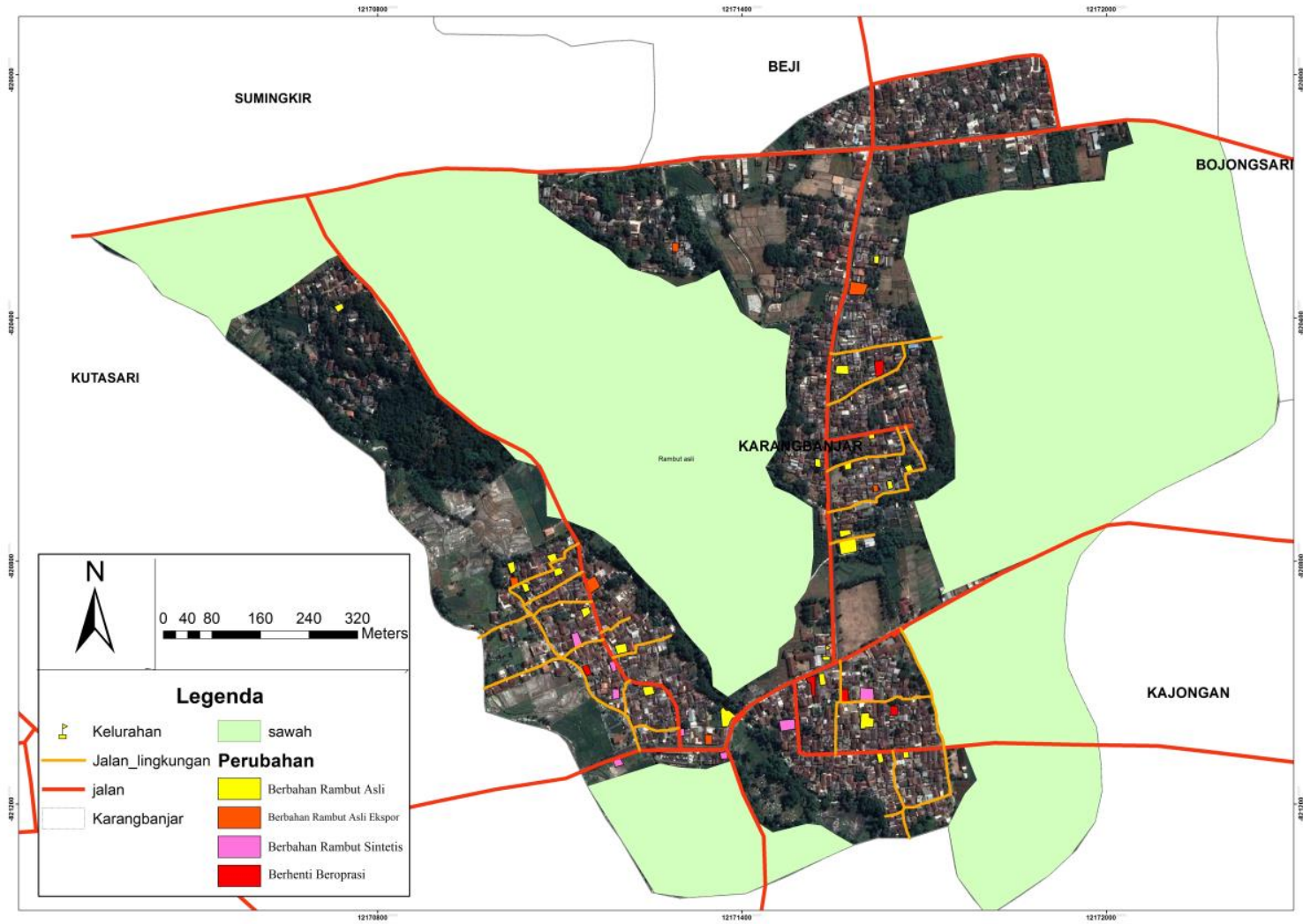

Sumber: Hasil Analisis Peneliti, 2019

Gambar 1. Peta Persebaran Industri Kreatif Rambut Palsu Berdasarkan Jenis Bahan Baku di Karangbanjar 
Metode penelitian yang digunakan adalah metode kualitatif dengan pendekatan studi kasus. Penggunaan metode kualitatif adalah untuk menggali data secara mendalam melalui wawancara in-depth dan observasi lapangan. Wawancara yang dilakukan adalah wawancara terbuka dengan beracuan pada kisi-kisi pertanyaan yang disusun atas dasar pemahaman terhadap teori yang terkait. Wawancara ini dilakukan dengan kisaran waktu dari bulan Mei - Juni 2019. Pendekatan studi kasus digunakan untuk mempelajari permasalahan penelitian yang berkaitan dengan kondisi sosial. Studi kasus pada penelitian ini didasarkan pada memandang industri kreatif sebagai fenomena kontemporer, mampu menjelaskan pertanyaan bagaimana, perkembangan industri kreatif rambut palsu merupakan sebuah kasus di Desa Karangbanjar, dan dikaji menggunakan berbagai kajian literatur terkait (Yin, 2015).

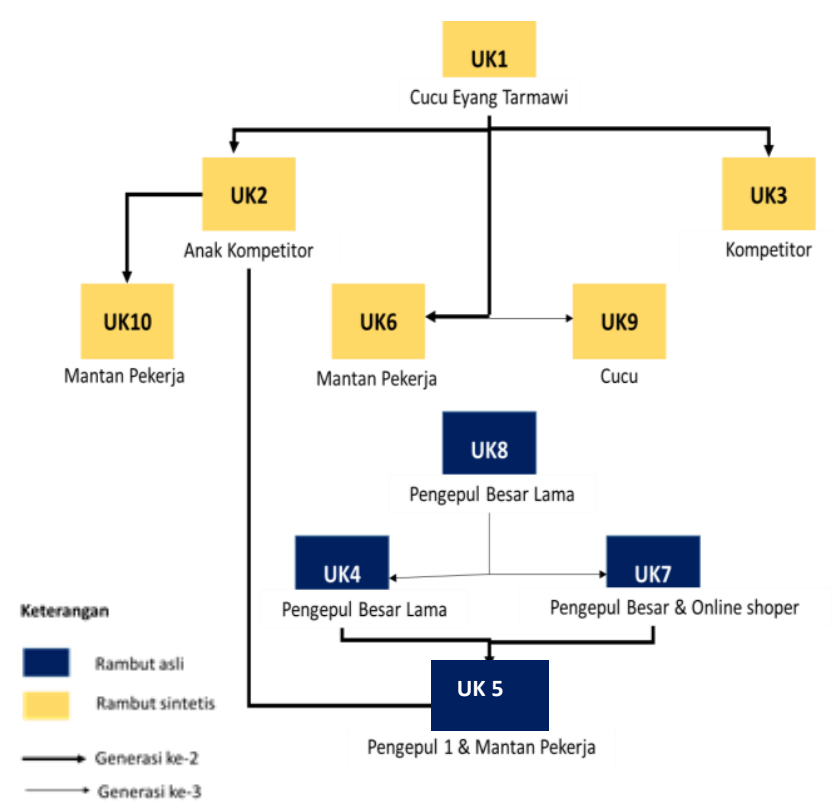

Sumber: Hasil Analisis Peneliti, 2019

Gambar 2. Bagan Kedudukan Unit Kasus

Pemilihan unit kasus adalah menggunakan teknik snowball berdasarkan beberapa kriteria seperti berdomisili di lokasi tersebut sekurang-kurangnya 25 tahun, bagian dari pelaku usaha, unit kasus selanjutnya merupakan saran unit kasus sebelumnya, dan informan kunci merupakan keluarga pencetus industri kreatif. Unit kasus yang menjadi informan dalam penelitian ini berjumlah
10 orang dengan satu informan kunci. UK 1 terpilih sebagai informan kunci berdasarkan fakta bahwa UK1 merupakan keluarga pendiri kerajinan rambut palsu, merupakan generasi kedua dan memiliki pengalaman lama dalam kerajinan rambut palsu serta merupakan local champion dalam pengembangan kerajinan rambut palsu.

\section{PROSES}

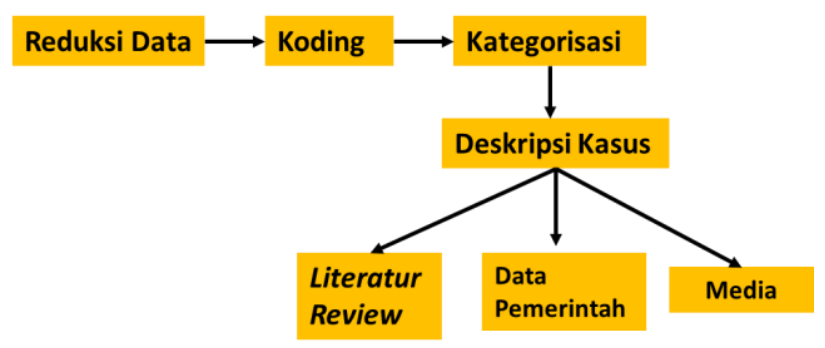

Sumber: Hasil Analisis Peneliti, 2019

Gambar 3. Bagan Proses Analisis

Data primer kemudian diolah melalui proses reduksi, koding dan kemudian dianalisis menggunakan deskriptif kualitatif (Moleong, 2013). Proses analisis deskriptif kualitatif didukung dengan teknik triangulasi data dengan mengkomparasi data primer dari lapangan, kajian literatur, dan penelitian terdahulu serta artikel yang mendukung (John, 2014). Validasi data dilakukan secara langsung melalui konfirmasi pernyataan antar unit kasus, hingga menghasilkan titik jenuh dimana tidak ada informasi baru yang didapatkan.

\section{HASIL DAN PEMBAHASAN}

Perkembangan industri kreatif rambut palsu mengandalkan modal utamanya berupa ide kreatif yang mendorong lahirnya inovasi. Inovasi menjadi langkah upaya adaptasi pelaku usaha untuk perkembangan industri kreatif rambut palsu mengikuti perubahan lingkungan yang dinamis (Sukarno, 2009). Perkembangan industri kreatif mencakup perluasan pasar serta daerah pemasok bahan baku, diversifikasi produk, perkembangan teknologi maupun proses produksi. Perkembangan tersebut dipengaruhi oleh adanya aliran inovasi. Aliran inovasi ini memiliki berbagai sumber ide yang diperoleh pelaku usaha untuk menghasikan inovasi terkait pengembangan industri kreatif. Aliran inovasi yang terjadi dalam mempengaruhi perkembangan industri kreatif merupakan wujud 
dari aktivitas perkembangan pemasaran dan perkembangan penggunaan bahan baku yang saling mempengaruhi.

\section{A. Rekonstruksi spasial perkembangan industri kreatif rambut palsu terhadap perkembangan aliran industri kreatif}

Pada awalnya produk rambut palsu yang dibuat berupa jalinan rambut asli panjang untuk sanggul (cemara) sebagai pelengkap busana wanita Jawa. Pelopor usaha ini adalah dukun bayi yang melakukannya sejak tahun 1951 karena berempati pada kesulitan calon pengantin yang berambut pendek. Usaha keluarga tersebut mendapat sambutan baik dari pelanggan dan makin dikenal luas dari informasi mulut ke mulut. Ketrampilan usaha diwariskan dan ditularkan melalui pekerja dan tetangga sekitar. Purbalingga kemudian dikenal sebagai pasar rambut secara regional hingga tahun 1965. Pasar nasional bertumbuh sejak adanya inovasi pembuatan konde atau sanggul jadi yang praktis baik gaya tradisional atau modern atas permintaan pasar sejak tahun 1980 sehingga muncul sentra home industry rambut palsu dengan 114 pengrajin UKM yang aktif. Inovasi produk wig dimulai guna memenuhi permintaan buyer internasional sejak tahun 1987 dan marak sekitar tahun 1990an. Permintaan dari Inggris cukup banyak karena produk Indonesia diakui lebih bagus dari India. Penggunaan rambut sintetis dimulai sejak berdirinya pabrik rambut palsu di Purbalingga tahun 2000an. Tahun 2019 ada 28 PMA didominasi investasi dari Korea Selatan yang menyerap 55.000 tenaga kerja. Pabrik menerima produk setengah jadi dari home industry. Pekerja yang kemudian keluar dari pabrik menularkan pengetahuannya dengan membuka atau ikut bekerja di satu home industry sehingga ketrampilan pengolahan rambut palsu (wig) dan bulu mata palsu sampai ke komunitas akar rumput melalui pelatihan maupun interaksi langsung sebagai pembelajaran social antar kerabat dan tetangga. Keterbatasan bahan baku menjadi kendala produksi akibat pemasok rambut asli adalah petani local yang aktivitasnya mencari rambut terhenti saat musim tanam padi berlangsung. Oleh karenanya area asal pasokan bahan baku meluas hingga ke Jawa Timur
Perkembangan industri kreatif rambut palsu baik inovasi jenis dan teknik produksi, area pemasaran, asal dan jenis bahan baku maupun pengembangan sumber daya manusia jika dilihat secara spasial terus mengalami perluasan. Pasar rambut palsu adalah daerah non muslim seperti Jakarta, Medan, Palopo dan luar negeri yaitu Inggris, Korea Selatan, dan China. Keunggulan Indonesia adalah produk hand made.

Aliran inovasi berkembang semakin luas dan beragam. Perkembangan pemasaran dan asal bahan baku memiliki pola yang sama yaitu berkembang dari tingkat desa, kabupaten, provinsi, Pulau Jawa, nasional hingga mampu ekspor ke negara lain. Perkembangan industri kreatif rambut palsu secara spasial digambarkan melalui Gambar 4.

Perkembangan pemasaran yang ditunjukkan bagan tersebut mengalami perluasan seiring berkembangnya waktu. Tujuan pemasaran dari produk rambut palsu mencakup beberapa kota besar dan kabupaten. Semakin luas jangkauan pemasaran, semakin beragam produk yang dihasilkan. Hal ini dikarenakan terdapat aliran inovasi didalam jaringan pemasaran. Ide yang dialirkan dalam jaringan pemasaran adalah berupa pengetahuan pelaku usaha terhadap produk lain yang sedang diminati pasar. Pelaku usaha mengadopsi ide produk yang sedang menjadi tren melalui media online untuk kemudian diterapkan dalam produk yang dihasilkan sesuai kondisi industri kreatif di Karangbanjar. Proses inovasi pelaku usaha tersebut terjadi karena adanya jaringan pemasaran yang menuntut supply punya kemampuan adaptif terhadap demand. Pelaku usaha mengenal produk rambut sintetis ketika jangkauan pemasarannya sudah mencakup pasar nasional. Pelaku usaha mengenal produk rambut asli setengah jadi yang disebut rambut remi (rambut yang dipisah pangkal dan ujungnya) ketika jangkauan pemasaran mencakup pasar internasional. Hal ini menunjukkan semakin luas jangkauan pemasaran maka perkembangan produk semakin pesat (Moore, 2014). Melalui jaringan pemasaran pelaku usaha mampu mengikuti tren secara dinamis. 


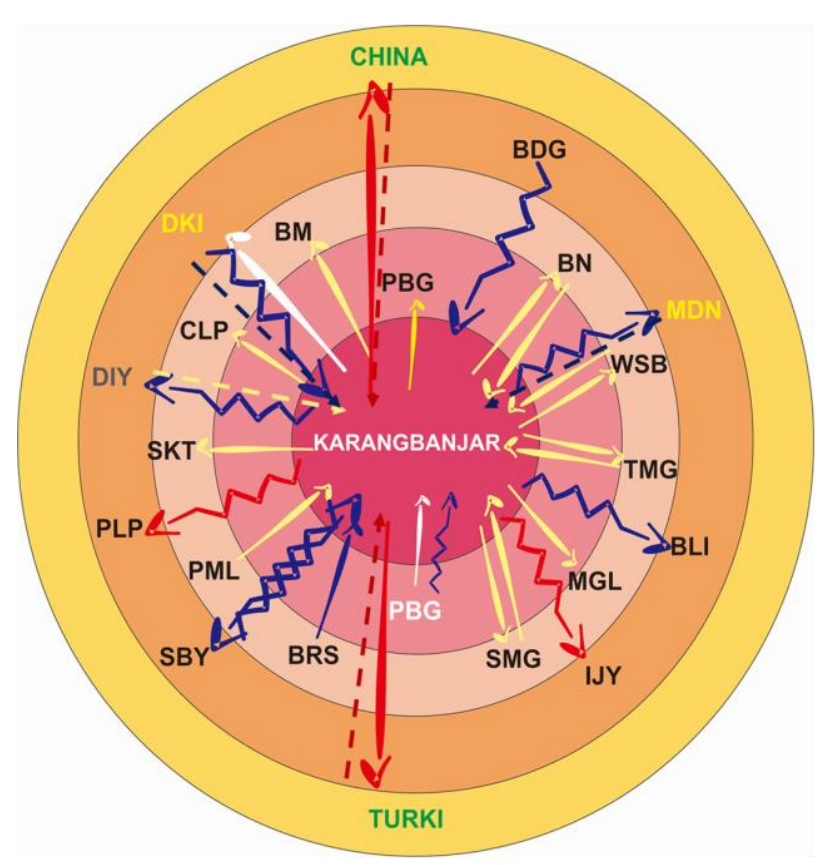

\begin{tabular}{|c|c|c|c|}
\hline \multicolumn{2}{|c|}{ KETERANGAN } & \multicolumn{2}{|c|}{ ALIRAN IDE } \\
\hline & KARANGBANJAR & $--\cdots$ & $2000<$ ALIRAN IDE \\
\hline & PURBALINGGA & $----\longrightarrow$ & $2010<$ ALIRAN IDE \\
\hline & JAWA TENGAH & $\begin{array}{l}\text { AKTOR } \\
\text { AKTOR }\end{array}$ & SALON/TOKO \\
\hline & INDONESIA & $\begin{array}{l}\text { AKTOR } \\
\text { AKTOR }\end{array}$ & $\begin{array}{l}\text { PABRIK } \\
\text { BUYER }\end{array}$ \\
\hline & DUNIA & AKTOR & PELATIHAN \\
\hline \multicolumn{2}{|c|}{ JEJARING PEMASARAN } & PBG & PURBALINGGA \\
\hline$\rightarrow$ & $1951-1965$ & BM & BANYUMAS \\
\hline$\rightarrow$ & $1966-1980$ & BN & BANJARNEGARA \\
\hline$\rightarrow$ & $1980-2000$ & WSB & WONOSOBO \\
\hline \multirow{3}{*}{$M \rightarrow$} & $2000<$ RAMBUT ASLI & TMG & TEMANGGUNG \\
\hline & $2000<$ RAMBUT SINTETIS & MGL & MAGELANG \\
\hline & $2010<$ RAMBUT ASLI & DIY & YOGYAKARTA \\
\hline$M$ & 2010< RAMBUT SINTETIS & SKT & SURAKARTA \\
\hline \multirow{3}{*}{\multicolumn{2}{|c|}{ ALIRAN BAHAN BAKU }} & PML & PEMALANG \\
\hline & & SMG & SEMARANG \\
\hline 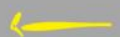 & & CLP & CILACAP \\
\hline$\longleftrightarrow$ & & BRS & BREBES \\
\hline & 1966-1980 & DKI & JAKARTA \\
\hline$<$ & $\begin{array}{l}1980-2000 \\
2000<\text { RAMBUT ASU }\end{array}$ & MDN & MEDAN \\
\hline MN & $2000<$ RAMBUT ASLI & SBY & SURABAYA \\
\hline en & $2000<$ RAMBUT SINTETIS & $\begin{array}{l}\text { BLI } \\
\text { BDG }\end{array}$ & $\begin{array}{l}\text { BALI } \\
\text { BANDUNG }\end{array}$ \\
\hline & 2010< RAMBUT ASLI & PLP & PALOPO \\
\hline$\leftrightarrow M$ & $2010<$ RAMBUT SINTETIS & IJY & IRIAN JAYA \\
\hline
\end{tabular}

Sumber: Hasil Analisis Peneliti, 2019

Gambar 4. Bagan Ilustrasi Perkembangan Industri Kreatif Rambut Palsu Berdasarkan Lokasi

Aliran inovasi jenis bahan baku dipengaruhi oleh perkembangan daerah pemasok bahan baku dan perkembangan pasar. Akan tetapi didalam aktivitas distribusi bahan baku tidak memiliki pengaruh signifikan terhadap aliran inovasi dalam pengembangan produk. Inovasi jenis bahan baku diperoleh melalui aliran supply bahan baku. Pelaku usaha mendapatkan ide menggunakan bahan baku sintetis ketika pemasok bahan baku berasal dari berbagai kota di Pulau Jawa. Hal ini tentunya akan mempengaruhi efisiensi proses produksi terkait jenis dan asal bahan baku. Perkembangan pasar, daerah pemasok bahan baku, dan ide produk yang dihasilkan merupakan hasil belajar pelaku usaha kepada berbagai sumber ide seperti keluarga, salon, pekerja lain, pabrik dan pemerintah. sehingga dalam aliran inovasi melibatkan berbagai aktor yang menjadi sumber inovasi pelaku usaha

\section{B. Aliran inovasi dalam perkembangan Industri kreatif}

Aliran inovasi yang terjadi dan mempengaruhi perkembangan industri kreatif memiliki beberapa sumber yang berbeda. Perbedaan sumber tersebut juga dipengaruhi oleh perkembangan tren produk. Perubahan zaman dan iklim usaha rambut palsu melatar-belakangi proses pelaku usaha untuk belajar terhadap hal yang baru. Pelaku usaha melakukan upaya adaptasi terhadap tren untuk mengikuti perkembangan zaman dengan terus berinovasi dalam aktivitas industri kreatif. Hal ini menunjukkan kreativitas pelaku usaha yang tinggi hingga mampu terus mengembangkan industri kreatif rambut palsu. Seperti pernyataan Moore (2014) bahwa tingkat kreativitas dilihat dari kemampuan pelaku usaha mengikuti perkembangan industri dari hal baru. Pelaku usaha menangkap ide melalui interaksinya dengan stakeholder dalam mata rantai pemasaran, penyediaan bahan baku dan pelatihan dengan cara belajar memproduksi permintaan gaya, warna, model, teknik dan bahan yang menjadi tren terbaru Aliran inovasi tidak hanya dipengaruhi oleh lokasi melainkan juga dipengaruhi tren dan waktu. Aliran inovasi dalam industri kreatif rambut palsu mengantarkan ide kreatif dari berbagai sumber kepada pelaku usaha. Media yang berperan mengalirkan ide kreatif juga beragam. Aliran inovasi pada perkembangan industri kratif rambut palsu Karangbanjar digambarkan melalui bagan pada Gambar 5. 


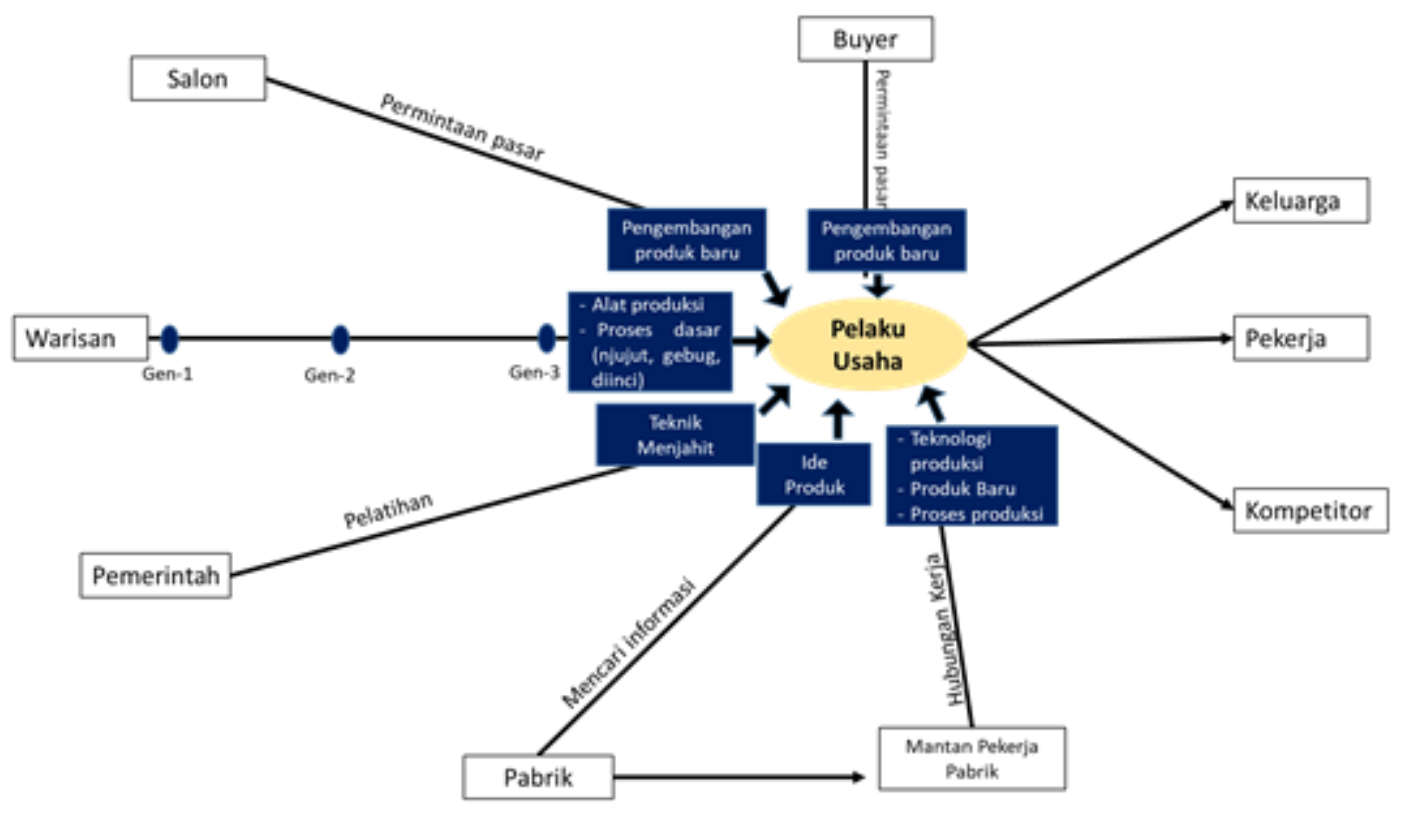

Sumber: Hasil Analisis Peneliti, 2019

Gambar 5. Aliram Inovasi dalam Industri Kreatif Rambut Palsu

Aliran inovai pada industri kreatif rambut palsu yang digambarkan melalui bagan pada Gambar 5 menunjukkan sumber ide, media yang menjadi perantara aliran ide, dan hasil ide yang diperoleh pelaku usaha. Beberapa aktor yang menjadi sumber dari aliran inovasi diantaranya keluarga yang mewariskan secara turun temurun, salon, buyer, mantan pekerja pabrik dan pabrik. Aliran inovasi yang sudah diterima pelaku usaha kemudian dialirkan kembali kepada pelaku usaha baru, keluarga maupun kompetitor. Beberapa tujuan aliran inovasi dari pelaku usaha adalah keluarga, pekerja dan kompetitor. Setiap sumber menghasilkan ide yang berbeda-beda yang kemudian mempengaruhi inovasi pelaku usaha baik dalam pengembangan teknologi, perkembangan produk maupun cara produksi. Aliran inovasi dalam menggambarkan hubungan kemitraan, transfer pengetahuan merupakan sumber daya yang intangible yang berperan mengembangkan industri kreatif rambut palsu (Liu, 2018).

Aliran inovasi dalam perkembangan industri kreatif telah menjadi media bagi pelaku usaha berinovasi untuk mengembangkan industri kreatif rambut palsu secara dinamis. Ide-ide yang mengalir dalam aliran inovasi kemudian mampu mengembangkan produk, perluasan pemasaran, penggunaan bahan baku. Hidayat dan Asmara (2017) menyatakan ide kreatif dapat muncul dalam bentuk inovasi karena ide tersebut menambahkan hal baru dalam aktivitas industri kreatif. Masing-masing perkembangan dari elemen industri kreatif saling berpengaruh satu sama lain. Aliran inovasi dalam mempengaruhi perkembangan industri kreatif diantaranya adalah sebagai berikut:

\section{Aliran Inovasi terhadap Perkembangan Produk} Perkembangan produk baru adalah bentuk kemampuan pelaku usaha mengembangkan industri kreatif secara dinamis. Hal ini karena pelaku usaha mampu mengikuti perkembangan tren permintaan. Upaya pelaku usaha dalam mengikuti tren adalah dengan melakukan inovasi terhadap permintaan produk. Inovasi yang mendukung perkembangan produk industri kreatif rambut palsu dipengaruhi aliran inovasi yang membawa ide-ide dari berbagai sumber diantaranya warisan turun temurun, salon, buyer, mantan pekerja pabrik dan pabrik besar. Melalui berbagai sumber tersebut pelaku usaha memperoleh ide produk untuk melakukan inovasi yang akan menghasilkan produk baru. Ide produk yang bersumber dari warisan turun temurun dialirkan melalui hubungan keluarga dimana orang tua mewariskan keahlian dan pengetahuan mengenai produk dan proses produksinya. 
Keahlian yang diwariskan turun temurun merupakan proses dasar dari pembuatan rambut palsu. Aliran inovasi diawali melalui hubungan keluarga dikarenakan unsur kepercayaan antar anggota keluarga untuk menjaga resep rahasia usahanya, sehingga pengetahuan tersebut diwariskan kepada anggota keluarganya (Chuluunbaatar dkk., 2014). Aliran ide produk yang bersumber dari salon dan buyer kemudian dilarikan melalui jaringan pemasaran. Ide produk yang didapatkan melalui aliran inovasi yang bersumber dari mantan pekerja pabrik adalah melalui hubungan pelaku usaha sebagai pemilik industri kreatif dengan pekerjanya. Sedangkan aliran inovasi yang bersumber dari pabrik adalah sikap aktif pelaku usaha untuk mencari informasi terkait tren produk.

"Salon memberikan sample dan menunjukan jahitannya juga dan memberikan rekomendasi alat jahit dari Korea juga. Pengemasan juga didapatkan ide dari salon. Tujuannya adalah untuk menjadikan barang mirip seperti pabrik dengan harga terjangkau untuk pasaran lokal."(Unit Kasus 3)."

Inovasi mengenai tren produk yang diperoleh dari salon, buyer, dan pekerja pabrik merupakan aliran inovasi yang terjadi secara langsung. Berbeda dengan inovasi dari pabrik yang terjadi secara tidak langsung yaitu dengan usaha masyarakat mencari sendiri informasi dari pabrik.

Aliran inovasi dalam mengembangkan produk tidak hanya berhenti pada pelaku usaha. Ide untuk melakukan inovasi yang dimiliki pelaku usaha kemudian dialirkan kembali kepada keluarga, pekerja, dan kompetitor. Hal inilah yang menjadikan banyaknya muncul pelaku usaha baru baik penerus usaha keluarga maupun perintis udaha. Aliran inovasi yang dialirkan kepada keluarga adalah bentuk kelanjutan dari mewariskan keahlian. Aliran inovasi dalam hubungan selain mengalir dari pekerja yang pernah bekerja di pabrik kepada pelaku usaha, juga mengalir dari pelaku usaha kepada pekerja. Selain itu aliran inovasi dari pelaku usaha juga sampai kepada kompetitor melalui iklim usaha yang sedang berkembang. Aliran inovasi mendukung pelaku usaha mampu melahirkan inovasi dan mengembangkan usaha secara dinamis (Moore, 2014; Sukarno, 2009).
"Kalau yang pertama bikin rambut remi itu fair lady kemudian akhirnya semuanya pada tahu. Kalau saya ya mungkin generasi ketiganya. Adanya remi baru tahun 2011 kesini lah itu ilmunya dari pabrik juga. Kalau yang pertama mengenal buyer itu fair lady." (Unit Kasus 4)

\section{Aliran Inovasi dalam jejaring Pemasaran}

Jejaring pasar merupakan faktor penting yang mendukung pengembangan industri kreatif rambut palsu. Kemampuan pelaku usaha dalam memperluas jejaring pemasaran tidak terlepas dari inovasi. Perluasan jejaring pemasaran seperti digambarkan melalui bagan pada Gambar 4 merupakan hasil inovasi pelaku usaha dalam mencari peluang pemasaran. Adanya aliran inovasi mempengaruhi pelaku usaha dalam mengembangkan jejaring pemasaran. Ide perluasan pasar diperoleh pelaku usaha dengan melihat tingkat permintaan konsumen di suatu daerah. Hal ini sejalan dengan pendapat Liu (2018) bahwa peluang pasar diperoleh karena kemampuan pelaku usaha dalam mencari informasi dan cepat dalam menanggapi permintaan pasar. Keberhasilan pelaku usaha dalam memasarkan produknya ke suatu daerah akan mendorong pelaku usaha lain mencoba memasarkan ke daerah yang sama.

"Dulu bapak saya kirimnya orang-orang luar negeri. Bapak saya kirim ke jakarta baru ke luar negeri biasanya cina yang ambil"(Unit Kasus 3)

"Dulu pertama luar negeri masuk itu jaman bapak saya dulu bikinnya cemara di jual ke Jakarta tahun 1963 saya masih SMP bapak saya jual 'cemara' ke Jakarta terus ada orang luar negeri mau rambut beli di Jakarta" (Unit Kasus 1)

Perluasan jejaring pemasaran memberikan dampak positif terhadap aliran inovasi dalam pengembangan produk. Aktor yang menjadi tujuan pemasaran menjadi sumber ide bagi pelaku usaha dalam berinovasi. Hal ini menunjukkan bahwa ide dapat dialirkan melalui jejaring pemasaran. Perluasan jejaring pemasaran membantu pelaku usaha dalam melihat tren pasar dan memberikan inovasi dalam perkembangan produk rambut palsu. 


\section{Aliran Inovasi terhadap Perkembangan penggunaan Bahan Baku}

Perkembangan penggunaan bahan baku dalam industri kreatif rambut palsu di Karangbanjar cukup beragam. Penggunaan bahan baku pada awalnya adalah memanfaatkan limbah rambut asli, namun seiring berkembangnya tren produk maka penggunaan bahan baku ikut berkembang. Berkembangnya produk rambut sintetis mendorong pelaku usaha memasok bahan baku rambut sintetis. Hal ini menunjukkan bahwa perkembangan produk berpengaruh terhadap perkembangan penggunaan bahan baku. Perkembangan perluasan asal bahan baku seperti pada Gambar 4 menunjukkan kemampuan pelaku usaha dalam berinovasi demi memenuhi pasokan bahan baku. Pelaku usaha akan mencari bahan baku di lokasi yang berbeda dengan pelaku usaha lain. Hal ini demi memenuhi kebutuhan bahan baku yang jumlahnya terbatas. Upaya pelaku usaha memperluas sumber bahan baku adalah untuk mencari bahan baku dengan harga rendah sehingga mendukung efisiensi produksi (Maulana, 2018).

"Cara memperoleh bahan baku adalah dengan mengumpulkan limbah rambut dari warga sekitar" (Unit Kasus 1).

"Semua orang bersaing mendapatkan bahan baku. Sedangkan pengusaha rambut terus banyak. Sedangkan di indonesia pengepul rambut ada di Jateng, Jabar, Jatim" (Unit Kasus 4)

"Kalau sudah kehabisan kita larinya ke Jawa Barat jawa timur. Luar jawa juga ada tapi sini enggak. Paling orang sini beli di luar jawa terus dikerjain lagi nanti kami beli terus dikerjain lagi disini" (Unit Kasus 7)

Aliran inovasi dalam mempengaruhi perkembangan produk, jejaring pemasaran dan perkembangan bahan baku telah menjadikan perkembangan industri kreatif rambut palsu dinamis. Selain beberapa aktor yang memiliki pengaruh besar dalam inovasi industri kreatif, terdapat peran pemerintah. Pemerintah turut andil dalam mendukung aliran inovasi melalui pengadaan pelatihan. Hal ini mendukung pengetahuan pelaku usaha dalam proses produksi menggunakan mesin jahit. Setiap sumber memiliki peran masing-masing dalam memberikan ide kepada pelaku usaha untuk berinovasi. Seperti pernyataan Liu (2018) bahwa cara merespon perubahan lingkungan yang dinamis adalah melalui proses belajar dari suatu kelompok dan transfer pengetahuan. Hal ini dapat menjadi alternatif bagi industri lain untuk mencari ide-ide dalam pengembangan inovasi.

\section{KESIMPULAN}

Rasa empati pada kesulitan orang lain mampu menjadi fondasi kuat bagi tumbuhnya cikal bakal usaha rambut palsu di daerah pedalaman Jawa Tengah. Keberhasilan usaha pelopor menjadi inspirasi menumbuhkan kompetisi usaha yang akhirnya mendorong perluasan transfer pengetahuan, area pemasaran dan inovasi usaha. Kemampuan adaptasi terhadap perubahan trend lingkungan usaha dalam melahirkan diversifikasi produk menjadi modal penting bagi keberlanjutan usaha. Aliran inovasi dalam perkembangan industri kreatif rambut palsu menggambarkan upaya pelaku usaha untuk beradaptasi dengan perubahan lingkungan melalui upayanya belajar terhadap hal yang baru. Inovasi pelaku usaha terus berkembang karena pelaku usaha memiliki pemikiran yang terbuka untuk mempelajari hal baru baik itu variasi produk, teknologi, pemasaran maupun proses produksi. Sumber pengetahuan dalam aliran inovasi bertambah seiring dengan perkembangan industri kreatif rambut palsu dalam merespon permintaan pasar baik dari luar maupun dalam negeri. Pertambahan lokasi aliran inovasi dipengaruhi oleh perluasan pasar, ditandai dengan koneksi antar jaringan daerah yang menjadi fokus pemasaran. Inovasi industri rambut palsu di Karangbanjar berkembang seiring munculnya pabrik rambut palsu baru yang tersebar di Kabupaten Purbalingga. Penularan pengetahuan dengan industri sejenis skala rumahan mengalirkan inovasi hingga level komunitas akar rumput.

\section{DAFTAR PUSTAKA}

Antoni, A. (2019). Berkurang 124,2 Ribu, Warga Miskin Jateng Masih 3,74 Juta Jiwa, Sindonews.com. Retrieved from https://daerah.sindonews.com/artikel/jate ng/7030/berkurang-1242-ribu-wargamiskin-jateng-masih-374-juta-jiwa 
Arifin, A., \& Sugiyanto, F. (2015). Value Chain Model of Plasma Core Partnership of Hair Production Creative Industry in Purbalingga Regency, Central Java Province. Procedia-Social and Behavioral Sciences, 211, 10-18. Doi: 10.1016/j.sbspro.2015.11.003

Boccella, N., \& Salerno, I. (2016). Creative Economy, Cultural Industries and Local Development. Procedia-Social and Behavioral Sciences, 223, 291-296. Doi: 10.1016/j.sbspro.2016.05.370

Chuluunbaatar, E., Luh, D.-B., \& Kung, S.-F. (2014). The Role of Cluster and Social Capital in Cultural and Creative Industries Development. Procedia-Social and Behavioral Sciences, 109, 552-557. Doi: 10.1016/j.sbspro.2013.12.506

Cobbinah, P. B., Black, R., \& Thwaites, R. (2013). Dynamics of Poverty in Developing Countries: Review of Poverty Reduction Approaches. Journal of Sustainable Development, 6(9), 25-35.

Cobbinah, P. B., Erdiaw-Kwasie, M. O., \& Amoateng, P. (2015). Rethinking Sustainable Development Within The Framework of Poverty and Urbanisation in Developing Countries. Environmental Development, 13, 18-32. Doi: 10.1016/j.envdev.2014.11.001

Fahmi, F. Z., McCann, P., \& Koster, S. (2017). Creative Economy Policy in Developing Countries: The Case of Indonesia. Urban Studies, 54(6), 1367-1384. Doi: 10.1177\%2F0042098015620529

Hidayat, A. R., \& Asmara, A. (2017). Creative Industry in Supporting Economy Growth in Indonesia: Perspective of Regional Innovation System. Paper presented at the IOP Conference Series: Earth and Environmental Science.

John, W. C. (2014). Penelitian Kualitatif dan Desain Riset, Memilih diantara Lima Pendekatan. Yogyakarta: Pustaka Pelajar.

Liu, C.-H. S. (2018). Examining Social Capital, Organizational Learning and Knowledge Transfer in Cultural and Creative Industries of Practice. Tourism Management, 64, 258270. Doi: 10.1016/j.tourman.2017.09.001

Maulana, Y. S. (2018). Analisis Faktor-Faktor Yang Mempengaruhi Pemilihan Lokasi Pabrik PT
Sung Chang Indonesia Cabang Kota Banjar. Jurnal IImiah ADBIS (Administrasi Bisnis), 2(2), 211-221.

Moleong, L. J. (2013). Metode Penelitian Kualitatif. Bandung: Remaja Rosdakarya.

Moore, I. (2014). Cultural and Creative Industries Concept-A Historical Perspective. Procedia-Social and Behavioral Sciences, 110, 738-746. Doi: 10.1016/j.sbspro.2013.12.918

Sukarno, G. (2009). Meningkatkan Kinerja Pemasaran Umkm Melalui Peran Lingkungan, Inovasi Produk Dan Kreatifitas Strategi Pemasaran. Ekuitas ISSN, 14110393.

Veselá, D., \& Klimová, K. (2014). Knowledge-Based Economy vs. Creative Economy. ProcediaSocial and Behavioral Sciences, 141, 413417. Doi: $10.1016 / j . s b s p r o .2014 .05 .072$

Yin, R. K. (2015). Studi Kasus (Desain dan Metode) Cetakan ke 14. Jakarta: PT. Rajagrafindo Persada. 